\title{
PROGRAMOVÝ MANAŽMENT S VYUŽITÍM METÓD MSP
}

\author{
L’ubomír Bombala*
}

\section{Úvod}

Z praxe riadenia vel'kých projektov sú známe prípady, ked' sú projekty realizované bez dodržania časového plánu a stanoveného rozpočtu. Manažment programov predstavuje prístup, vd'aka ktorému sa spoločnostiam často darí uskutočňovat' náročné a rozsiahle zmeny.

Ciel'om tohto príspevku je nadviazat' na článok o metóde PRINCE2 pre projektový manažment uvedenej v [9] a d'alej vysvetlit', čo je programový manažment, a ako sa dá využit' na transformáciu stratégie spoločnosti do koordinovaného portfólia projektov. Množstvo vynakladaných peňazí, času a úsilia predstavuje vel'kú príležitost' pre organizácie, aby využili a osvojili si prístupy manažmentu programov. Schopnost' rýchlo, efektívne a účinne implementovat' zmenu je spojená so získaním konkurenčnej výhody.

Zmeny v ekonomike vytvárajú tlak na organizácie a nútia ich do výrazných zmien v záujme zvýšenia produktivity. Silná konkurencia, zmeny obchodných modelov, nové technológie, deregulácia, tlak na náklady, globalizácia atd'. nútia organizácie podnikat'viac a viac zmien s nezvyčajnou komplexnost'ou a rýchlost'ou.

OGC (Office of Government Commerce), do ktorého portfólia patrí aj PRINCE2, investovalo značné prostriedky do vývoja produktov $\mathrm{v}$ oblastiach projektového a programového manažmentu, manažmentu rizika a manažmentu IT služieb. OGC vytvorilo metódu pre programový manažment MSP (Managing Succesful Programmes) $[3,4]$.

MSP prestavuje rámec pre programový manažment, pre identifikáciu prínosov programu a realizáciu programu. Programový manažment sa zaoberá zmenou v spoločnosti, ktorá je založená na vízii spoločnosti. Poskytuje pohl’ad na to, kam smeruje organizácia. Vízia dáva interným a externým zákazníkom organizácie definíciu toho, čo možno očakávat’ od organizácie v budúcnosti. Popisuje úrovne služieb po ich transformácii do terminológie MSP. Vízia zoznamuje záujmové strany s konečným ciel’om všetkých programov organizácie.

MSP reprezentuje overenú metódu pre programový manažment v úspešnej realizácii transformačnej zmeny prostredníctvom aplikácie programového manažmentu. MSP definuje programový manažment, ako činnost' spojenú s vykonávaním koordinovanej organizácie, smerovania a implementácie portfólia projektov a transformačných aktivít (napr. programov) s ciel'om dosiahnut' výstupy a realizovat' prínosy, ktoré majú strategický význam pre podnikanie [7].

\footnotetext{
* Ing. L’ubomír Bombala, DHL IT Services Europe, V Parku 2308/10, 14800 Praha 4, ext. doktorand, Katedra spojov, FPEDAS, ŽU v Žiline

tel: +420288802185

e-mail: lubomir.bombala@dhl.com
} 


\section{Metóda MSP}

\subsection{História MSP}

V septembri 2007 publikoval OGC tretiu revíziu globálne uznávanej metódy MSP. Prvá verzia bola vydaná v roku 1999, pričom rozvinula koncepciu obchodnej zmeny z projektov. Využívala vývojové materiály od spoločnosti Calyx Consulting Limited s podporou a spoluprácou od Programme Consulting Limited. V roku 2003 bola vydaná druhá verzia, ktorá reflektovala rastúcu vyspelost' modelu. Verzia z roku 2007 zostáva verná originálnemu konceptu, pričom je doplnená o nové poznatky z tejto oblasti $[4,8]$. Boli pridané nové nástroje a techniky, pričom vysvetlenia sú viac do híbky, aby pomohli organizáciám efektívnejšie implementovat’ programový manažment.

\subsection{Funkcie v MSP}

MSP definuje úlohy a zodpovednosti všetkých, ktorí sú potrebnou súčastou vedenia programu. Efektívne vedenie programu je dosiahnuté prostredníctvom kvalifikovanej tvorby rozhodnutí a flexibilného systému manažmentu. Ku kl'účovým zainteresovaným stranám patria [8]:

\section{Sponsoring Group (Skupina sponzorov)}

Reprezentuje skupinu senior manažérov, ktorí sú zodpovední za:

- Rozhodnutia o investíciách

- Definovanie smerovania podnikania

- Zaistenie trvalého celkového zamerania programu k strategickému smerovaniu organizácie

Sponsoring group vymenuje funkciu senior responsible owner, ktorý je jej súčast'ou a je rovnocenný s inými členmi sponsoring group. Úlohy sponsoring group môže dobre vykonávat' existujúca správna rada alebo predstavenstvo organizácie.

\section{Senior Responsible Owner (SRO - senior vlastník programu)}

SRO je v zásade zodpovedný za program, zaist'uje, že program dosahuje stanovené ciele a realizuje očakávané prínosy. Osoba poverená touto úlohou by mala byt' schopná viest' program s energiou a schopnost'ou presadit' sa, musí byt' splnomocnená na riadenie programu a vykonávanie rozhodnutí. Musí mat' dostatok pracovných skúseností a autoritu na poskytovanie vedenia programového tímu a prevzatie zodpovednosti za dodanie.

\section{Programme Manager (Programový manažér)}

Programový manažér je zodpovedný za vedenie a manažovanie nastavenia programu smerom $\mathrm{k}$ dodaniu nových kapacít a realizácie prínosov. Programový manažér má primárnu zodpovednost' za úspešné dodanie nových kapacít a ustanovenie vyžadovaných riadiacich opatrení.

\section{Business Change Manager (Manažér obchodnej zmeny)}

Zatial' čo je programový manažér zodpovedný za dodanie kapacít, manažéri obchodnej zmeny sú zodpovední za realizáciu výsledných prínosov zabudovaním týchto kapacít do obchodných operácií. Osoby menované na funkcie programových manažérov a manažérov obchodných zmien musia byt' schopné úzko spolupracovat', aby sa zaistilo, že sú dodané správne kapacity a sú najlepšie využité. Činnosti manažmentu obchodnej zmeny zasahujú svojimi dôsledkami 
do programov a ich projektových organizácií, majú tiež dosah na obchodné operácie. Každá oddelená obchodná organizácia, ktorá je ovplyvňovaná programom by mala mat' vlastného predstavitel'a pre manažment obchodnej zmeny.

\section{Programme Office (Programový úrad)}

Program predstavuje vel'ký záväzok, často ovplyvňuje vel'ký počet l’udí a organizácií a generuje vel'ké množstvo informácií. Nervovým a informačným centrom programu je programme office. Všetky informácie, komunikácia, monitorovacie a riadiace aktivity pre program sú koordinované cez programme office.

\subsection{Aplikácia MSP}

MSP sa snaží adresovat' tri typy programov, pričom každý vyžaduje odlišný dôraz a intenzitu zdrojov a riadenia:

- Programy vedené víziou, ktoré začínajú jasne definovanou víziou, majú prístup zhora nadol a sústred’ujú sa na strategické a inovatívne príležitosti s radikálnou transformáciou podnikania, kultúry alebo oboch súčasne.

- Spôsobené programy sa vyvinú zo súčasných nekoordinovaných iniciatív, ked' sa objaví rozpoznanie hodnoty plynúcej zo zjednotenia prístupu so vzniknutou víziou a konečným ciel'om.

- Programy zabezpečujúce zhodu sa označujú za povinné programy. Organizácie nemajú na výber, či zmenu uskutočnia napríklad $z$ dôvodov trhových síl alebo potenciálneho negatívneho dopadu nevykonania zmeny.

$\mathrm{Na}$ rozdiel od projektového manažmentu, ktorý stavia na určitostiach, programový manažment rozoznáva a využíva mnohoznačnost', v rámci ktorej existuje.

\subsection{Princípy programového manažmentu}

MSP poskytuje spoločný rámec pre pochopenie všetkých programov, pretože je založený na princípoch, ktoré sú:

- Univerzálne v tom, že sa aplikujú na každý program,

- Sebapotvrdzujúce v tom, že boli vyskúšané v praxi,

- Splnomocňujúce, pretože dávajú vykonávatel'om MSP schopnost' alebo právomoc ovplyvnit' a formovat' transformačnú zmenu.

\section{Rámec MSP}

Rámec MSP je založený na troch hlavných konceptoch [4,5]:

- MSP Princípy. Tie sú odvodené z pozitívnych a negatívnych ponaučení zo skúseností z programov. Sú to spoločné faktory, ktoré podporujú úspech každej transformačnej zmeny,

- Riadiace témy MSP. Tieto definujú prístup organizácie k programovému manažmentu. Umožňujú organizáciám dat' dokopy správne vedenie, realizačný tím, organizačné štruktúry, kontroly a dávajú najlepšiu šancu na úspech,

- Transformačný tok MSP. Poskytuje cestu cez životný cyklus programu od jeho koncepcie až k dodaniu novej kapacity, výstupov a prínosov.

Rámec MSP je navrhnutý tak, aby umožnil realizáciu transformačnej zmeny a dosiahnutie strategických ciel'ov organizácie. Programy existujú vo vypätej oblasti medzi strategickým smerovaním organizácie, realizáciou zmien v schopnostiach organizácie 
prostredníctvom projektov a potrebou udržiavat' výkonnost' a stabilitu podnikania zatial' čo realizujeme a využívame prínosy z investícií. Rámec MSP je znázornený na obr. 1 .

MSP obsahuje dokument označovaný ako blueprint, ktorý predstavuje náčrt štruktúry a zloženia organizácie po prevedení zmeny, ktorá demonštruje schopnosti obsiahnuté vo vízii. Blueprint predstavuje detailný popis organizácie v termínoch obchodných procesov, l'udí, informačných systémov, prostriedkov a ich dát. Blueprint pomáha udržiavat' pozornost' programu na dodanie novej kapacity.

Spúšt’acím mechanizmom pre úvodný krok - identifikovanie programu je programový mandát, ktorý poskytuje strategické ciele pre program. Ciele dané v programovom mandáte sú d'alej rozvinuté do dokumentu programme brief. Pred d'alším pokračovaním je potrebné jeho formálne schválenie skupinou sponzorov programu a SRO.

Programme brief je klúčovým vstupom do kroku definovanie programu. Predstavuje základ pre vytvorenie definície programu, plánov a stratégie pre riadenie programu. Predtým, ako je program formálne zahájený, je opät potrebný súhlas skupiny sponzorov programu a SRO.

Ustanovenie vedenia programu je dohodnuté a implementované v kroku manažovanie tranží. Definícia programu a plány sú základom pre kroky dodávanie kapacity a realizovanie prínosov.

Projekty a aktivity sú združené do tranží. Každá tranža zabezpečuje krokovú zmenu v schopnostiach organizácie, po ktorej ukončení je možné zhodnotit' prínosy. Aktivity krokov dodávanie kapacít a realizácia prínosov sú opakované pre každú tranžu. Koniec každej tranže poskytuje dôležitý kontrolný bod, v ktorom môže byt' program formálne zhodnotený vzhl'adom na stupeň dosiahnutia očakávaných výstupov a meratel'nej realizácie prínosov. Monitorovanie pokroku naprieč programom poskytuje priebežné hodnotenie kritických otázok, ako sú napr.: Vyvíja sa program podl'a očakávaní? Je obchodný prípad stále platný a relevantný? Potrebujeme niečo zmenit', aby sme usporiadali program?

Krok ukončovanie programu nastáva, ked' je program dokončený - blueprint programu bol zrealizovaný a kapacity potrebné na dosiahnutie vízie sú implementované. Za týmto krokom môže nasledovat' ešte d'alšie hodnotenie a meranie kontinuálnej realizácie prínosov. 


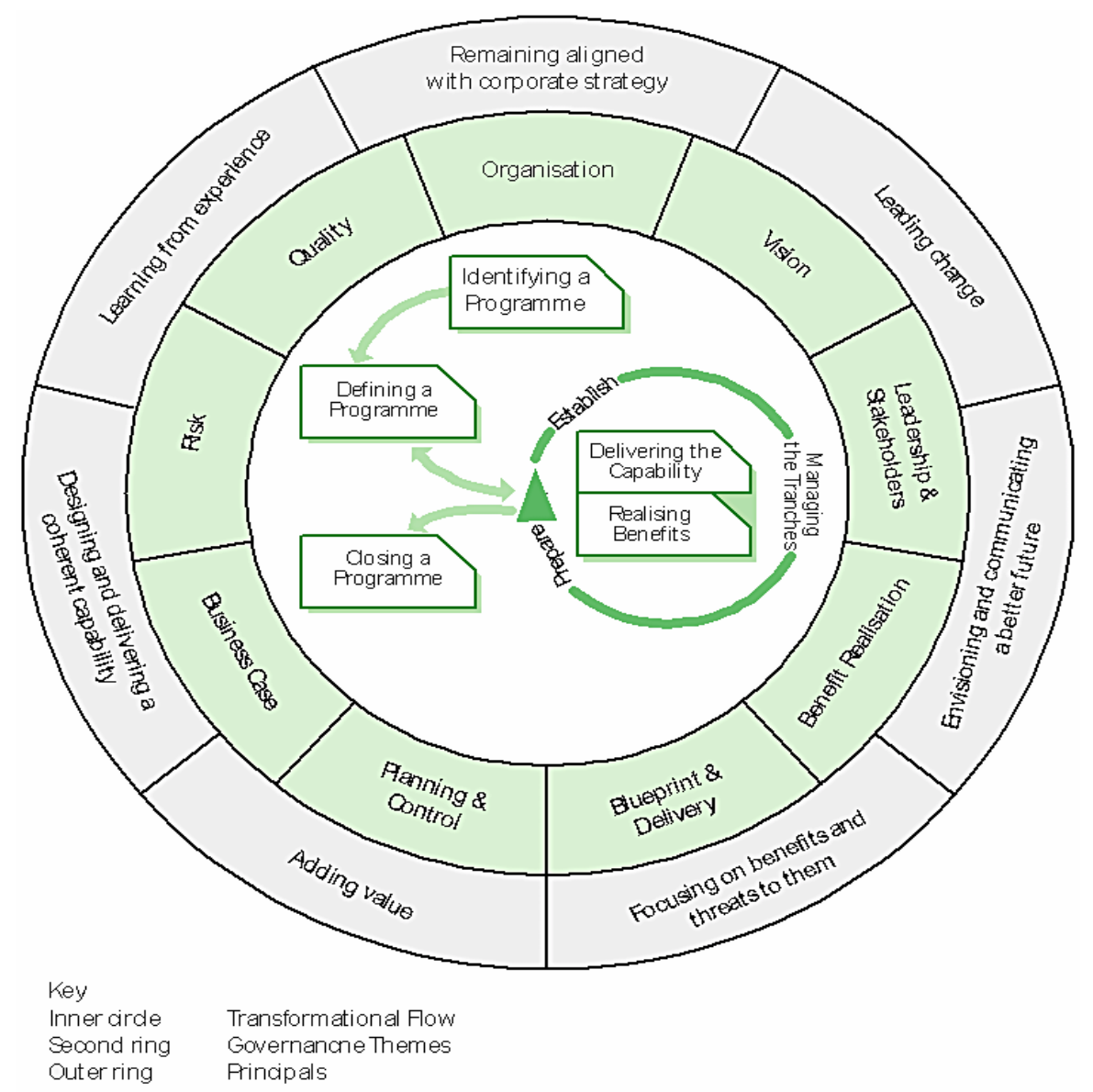

Obr. 1 Rámec MSP, prebrané z [10]

\subsection{Princípy MSP [5]}

MSP predstavuje princípy programového manažmentu, ktoré je potrebné aplikovat' na každý program, boli overené praxou a pomáhajú jednotlivcom vykonávat' úspešné programy:

\section{- Zachovávanie súladu s korporátnou stratégiou}

Úspešný program ponúka dôležitý príspevok vzhl'adom na dosiahnutie firemných výkonnostných ciel'ov. Programy by si mali udržovat' dobré prepojenia s premenlivou firemnou stratégiou, aby sa zaistilo, že výstupy programu zostávajú v súlade so stratégiou.

\section{- $\quad$ Vedenie zmien}

Úspešný program bude rezultovat' v lepšej budúcnosti pre organizáciu. Avšak nie je možné sa dočkat' lepšej budúcnosti bez jasného vedenia. Programové vedenie musí poskytovat' jasné smerovanie, vytvárat' dôveru, aktívne angažovat' zúčastnené strany, menovat' správnych l'udí v správnom čase, byt' schopný žit' s neistotou, riešit' problémy s kreatívnymi riešeniami a podporovat' zmenu, kým sa nové spôsoby práce nestabilizujú a ustália.

- Predvídanie a komunikovanie lepšej budúcnosti

Ďalší dôležitý aspekt posunu k lepšej budúcnosti je schopnost' lídrov popísat' jasnú víziu tejto budúcnosti. Prehlásenie o vízii zobrazuje želaný budúci stav prostredníctvom popísania nových služieb, zlepšených úrovní služieb alebo inovatívnych spôsobov práce so zákazníkmi. Vízia sa využíva na komunikáciu konečného ciel’a programu a na získanie podpory od záujmových strán.

\section{- $\quad$ Sústredenie sa na prínosy a ich možné ohrozenia}

Konečný úspech programu je posudzovaný podl'a jeho schopnosti realizovat' prínosy strategického významu. Všetky činnosti v rámci programu by mali byt' zamerané na realizáciu prínosov. Toto zahŕňa efektívny manažment rizík, ktoré môžu ovplyvnit’ tieto prínosy. 


\section{- $\quad$ Pridanie hodnoty}

Program je platný, iba ked' pridáva hodnotu projektom a transformačným aktivitám. Prínosy programov by mali byt' nadradené prínosom, ktoré identifikujú a preukazujú projekty.

\section{- Návrh a realizácia koherentnej kapacity}

Aby bol program schopný realizovat' strategické prínosy, bude potrebné dodat' zdokonalenú kapacitu. Toto by malo byt' vnútorne koherentné tzn. požiadavky na kvalitu sú optimalizované a uvol'nené do prevádzkového použitia, aby sa zaistila maximálna prírastková kapacita s minimálnymi negatívnymi dopadmi na organizáciu.

\section{- Učenie sa zo skúseností}

Program by mal predstavovat' učiacu sa organizáciu, ktorá reflektuje na svoje vykonávanie a hl'adá zlepšenia. Preto bude program prebiehat' lepšie, ked' si členovia manažmentu osvoja prístup poslucháčov.

\subsection{The Governance Themes (Riadiace témy) [5]}

Predstavujú sadu doporučení, ktoré vysvetl’ujú, ako majú byt' kl’účové elementy programu realizované počas životného cyklu programu. Oblasti riadenia predstavujú subjekty, ktoré bude potrebné priebežne manažovat' vo väčšej či menšej miere na dennej báze. MSP popisuje 9 riadiacich tém, každá $\mathrm{z}$ nich približuje konzistentné riadenie potrebné na manažment programu. Tieto riadiace témy sú:

- Organisation (Organizácia)

Stanovenie jasnej a efektívnej organizácie je kritické pre úspech programu. Zaistenie, že organizácia programu spíňa potreby programu je nielen počiatočná, ale aj priebežná úloha. Efektívna programová organizácia vyžaduje kombináciu definovaných úloh, jasné zodpovednosti a manažérske štruktúry spolu s usporiadaním reportov, ktoré sú potrebné na realizáciu želaných výstupov programu. Programový manažment je najefektívnejší, ked' sú problémy vol’ne diskutované a riziká vyhodnocované otvorene. Toto vyžaduje štýl vedenia a kultúru, ktorá podporuje tok informácií medzi projektmi a programom. Táto riadiaca téma popisuje to, ako by sa malo aplikovat' riadenie cez skupinu sponzorov a programovú radu, poskytuje rady týkajúce sa úloh a zodpovedností pre SRO, manažéra obchodnej zmeny a programového manažéra. Rovnako doporučuje aj d’alšie úlohy.

\section{- Vision (Vízia)}

Vízia je potrebná pre realizáciu každého programu, MSP objasňuje jej kl'účový obsah. Vízia je obrazom lepšej budúcnosti. Je to podklad pre výstupy a dodávané prínosy programu. Deklarácia vízie sa používa na komunikovanie konečného ciel'a programu, čím je navonok vyjadrujúci popis budúceho stavu nasledujúceho realizáciu programu. Dobrá deklarácia vízie by mala opisovat' budúci stav, byt' l'ahká na pochopenie a komunikáciu, aplikovatel'ná na široký rozsah zúčastnených strán, popisovat' želatel'nú a pôsobivú budúcnost', ktorá zodpovedá stupňu transformačnej zmeny, byt' verifikovatel'ná, krátka a zapamätatel'ná.

\section{- Leadership and Stakeholder Engagement (Vedenie a zaangažovanie zúčastnených strán)}

Táto téma je kritická pre akýkol'vek program, zmena vyžaduje efektívne vedenie, MSP zdôrazňuje potrebu nielen identifikovat' a komunikovat' so záujmovými stranami, ale tiež poskytuje analytické nástroje na vytvorenie lepšieho pochopenia ich potrieb, postrehov a priorít. Lídri používajú deklaráciu vízie na ovplyvnenie a presvedčovanie záujmových strán, aby sa postavili za užitočnú budúcnost'. Záujmové strany predstavujú jednotlivcov alebo skupiny, ktoré majú záujem na programe, jeho výstupoch a prínosoch. Skúsení lídri dokážu využívat' komunikáciu, vízie a metafory, aby tak manažovali vnímanie súčasnej reality záujmovými stranami, prínosnú budúcnost' a napätie medzi dvomi: vytvorit' a udržiavat' organizačný impulz a odhodlanie na zmenu. 


\section{- Benefits Realisation Management (Manažment realizácie prínosov)}

Predstavuje hlavný rozdiel medzi projektmi a programami. Aktívne využívanie príležitostí, ktoré sú ponúkané investíciami do výsledkov projektov je komplexný proces. Každý prínos má svoj vlastný profil a podporný plán na realizáciu zmien a prínos zisku. Prínos je meratel’né zlepšenie, ako výsledok výstupu, ktoré je vnímané záujmovými stranami ako výhoda. Program predstavuje transformačnú zmenu, umožnenú výstupom projektu a/alebo transformačnou činnost'ou, ktorej výsledkom je želaný výstup. Prínosy by mali prispiet' k jednému alebo viacerým strategickým organizačným ciel’om. Manažment realizácie prínosov by mal zabezpečit', že prínosy sú identifikované a definované, že obchodné oblasti sú zaviazané realizácii ich prínosov, že prínosy sú merané a zaznamenávané, a že je súlad medzi požadovanými prínosmi programu a strategickými ciel'mi organizácie.

\section{- Blueprint Design and Delivery (Návrh blueprintu a dodanie)}

Blueprint je podkladom pre program, je to vlastne stav organizácie po skončení programu, a súčasne aj štartovací bod pre program. Transformácia sa uskutočňuje v krokových zmenách organizovaných do tranží. Zatial'čo vízia poskytuje opis požadovaných výstupov programu $\mathrm{v}$ termínoch orientovaných na zákazníka, blueprint ich rozvádza, aby poskytol použitel'ný základ pre modelovanie prínosov a na návrh projects dossier (napr. skupina projektov, ktorá bude dodávat' výstupy vyžadované programom).

- Planning and Control (Plánovanie a kontrola)

Táto téma detailne vysvetl'uje, ako vytvorit' plán programu a spravovat' vnútornú kontrolu. Plánovanie a kontrola sú kl'účom k úspechu každého transformačného programu, ale mal by byt' vnímaný ako zretel'ne oddelené koncepcie a aktivity. Príprava programového plánu vyžaduje spracovanie vel'kého množstva informácií a rozsiahle konzultácie k tvorbe plánu. Programový plán by mal obsahovat’ informáciu týkajúcu sa zväzku projektov (časový rozvrh, náklady, výstupy, závislosti), riziká a predpoklady, plán ukazujúci tranže, plán zmien, monitorovacie a riadiace aktivity a výkonnostné ciele. Kontrola programu poskytuje podporné činnosti a procesy, ktoré bežia naprieč programom, aby zlepšili dodanie, minimalizovali dopad nejasností a priniesli určitost', kdekol’vek je to možné.

- Business case (Obchodný prípad)

Obchodný prípad je potrebný pre každý program, MSP zdôrazňuje potrebu zastrešujúceho obchodného prípadu pre celý program a každý projekt bude mat' svoj vlastný obchodný prípad. Obchodný prípad je zoskupenie špecifických informácií o hodnote prínosov, rizikách ich dosahovania, nákladoch na dodanie blueprintu a časových rozvrhoch pre dodanie. Programový obchodný prípad poskytuje dôležitý test životaschopnosti programu. Mal by byt' použitý na zodpovedanie otázky: „Vypláca sa ešte stále investovanie do programu?“ Pretože otázka životaschopnosti je stále aktuálna počas celého programu, je obchodný prípad aktívne udržiavaný počas celého programu a priebežne aktualizovaný s novými informáciami.

- Risk management and issue resolution (Manažment rizika a riešenie problémov) Táto oblast' poskytuje rady a vedenie, ako sa vyhnút' realizácii udalostí, ktoré spôsobia neúspech programu. Nesústred'uje sa iba na potrebu manažmentu hrozieb, ale tiež využíva príležitosti. Rozoznáva 4 perspektívy: Strategické, programové, operačné a projektové riziko. Riziko je neurčitá udalost' alebo súbor udalostí, ktorá pokial' nastane, bude mat' dopad na dosiahnutie ciel'ov. Tieto efekty nie sú všetky škodlivé, pretože riziko môže byt' ako hrozbou, tak aj príležitost'ou. Úlohou manažmentu rizika je zaistit', že program vykonáva nákladovoefektívne využitie procesu manažment rizika, ktoré zahŕňa sériu dobre definovaných krokov. Zámerom je podpora lepšej tvorby rozhodnutí cez dobré pochopenie rizík a ich pravdepodobných dôsledkov. Na druhej strane problémy sú udalosti, ktoré sa udiali, neboli plánované a v súčasnosti nejakým spôsobom ovplyvňujú program, je potrebné sa nimi aktívne zaoberat' a riešit' ich. Riziká, pokial' sa vyskytnú, stanú sa problémami. Úlohou riešenia problémov je zabránit' ohrozeniu šancí programu na dosiahnutie úspešného výstupu. 


\section{- Quality management (Manažment kvality)}

sa sústred'uje na oblasti optimálneho manažmentu l'udí, zdrojov, dodávatel'ov, procesov, prostriedkov, informácií a strategického usporiadania. Manažment kvality v programe zaist'uje, že zúčastnené strany sú spokojné, že ich plánované prínosy majú najlepšiu šancu na realizáciu a splnia ich očakávania. Ak program neaplikuje efektívne manažment kvality do svojich aktivít, jeho prostriedky a výstupy s menšou pravdepodobnostou splnia účel, s následnými nepriaznivými dôsledkami na výstupy a požadované prínosy. Manažment kvality musí byt' aktivita, ktorá beží priebežne počas života programu a aj neskôr, sústredí sa na pomoc pri dosahovaní strategických ciel'ov.

\subsection{Transformačný tok [5]}

Transformačný tok je termín, ktorý sa používa na označenie životného cyklu programu. Termín „tok“ odzrkadl’uje rozvíjajúcu sa povahu cesty, ktorou sa program uberá a úpravy, ktoré bude potrebné urobit'. Transformačný tok MSP programu s hlavnými procesmi a klúčovými riadiacimi dokumentmi spojenými s realizáciou programu je znázornený na obr. 1. Transformácia je dosiahnutá cez sériu iteratívnych, vzájomne prepojených krokov, kde každý proces môže vyžadovat' viac ako jednu iteráciu než začne d’alší. Program potom prechádza nasledovnými krokmi alebo etapami:

1. Identifying a Programme (Identifikovanie programu) berie načrtnutú myšlienku a mení ju na obchodnú koncepciu, ktorá získa strategickú podporu naprieč analýzou zúčastnených strán, vyjasnením strategických požiadaviek a trhovou konzultáciou. Zvyčajne programový mandát dáva dokopy strategické (vyššej úrovne) ciele programu z organizačných strategických plánov a relevantných firemných politík, plus náčrt deklarácie vízie. Toto zhrnutie je potom d'alej prepracované do dokumentu programme brief, ktorý definuje očakávané prínosy, náklady, časové rozvrhy a riziká týkajúce sa navrhovaného programu. Tento dokument vyžaduje formálne schválenie SRO a skupinou sponzorov predtým, ako program bude pokračovat' do d'alšej etapy transformačného toku. Hlavné činnosti v tejto etape sú: Určenie sponzora programu, potvrdenie programového mandátu, vymenovanie SRO, vytvorenie dokumentu program brief, vytvorenie terminológie pre definíciu programu, kontrolu a schválenie pokračovania.

2. Defining a Programme (Definovanie programu) potvrdzuje víziu, podniká detailnú analýzu možností a navrhuje programovú infraštruktúru. Výsledkom je obchodný prípad a strategický záväzok. Tento proces poskytuje podklady pre rozhodovanie či pokračovat' s programom alebo nie. Toto je etapa, kde sa vykonáva detailná definícia a plánovanie programu. Programme brief sa používa, ako štartovací bod pre vytvorenie dokumentu definícia programu, ktorý sa vyvíja, aby vysvetlil, čo chce program robit', ako to chce robit', kto je do programu zapojený, ako sa to bude kontrolovat' a odôvodnenie pre d'alšie pokračovanie. Hlavné činnosti v tejto etape sú: Vytvorenie tímu na definovanie programu, potvrdenie vízie, vytvorenie blueprintu, stanovenie prínosov a ich schválenie, identifikácia záujmových strán, návrh portfólia projektov a identifikovanie tranží. Návrh organizačnej štruktúry programu, vytvorenie obchodného prípadu pre program, usporiadanie riadiacich orgánov programu, vývoj komunikačného plánu, vytvorenie plánu realizácie prínosov, vytvorenie plánu programu a schválenie pokračovania.

3. Managing the Tranches (Manažovanie tranží) popisuje cyklické aktivity spojené s manažovaním a poskytovaním koordinovaného rozhrania medzi projektmi, zmenou v podnikaní a strategickým smerovaním. Účelom procesu manažovanie tranží je implementovat' definované riadiace usporiadanie pre program. Ovládanie znamená funkcie, procesy a procedúry, ktoré definujú ako je program nastavený, manažovaný a kontrolovaný. Počas priebehu programu, špeciálne na konci každej tranže, preveruje efektívnost' riadiaceho 
usporiadania a pokračujúcu životaschopnost' programového obchodného prípadu. Počas priebehu programu sa jeho charakteristiky často menia, tomu sa musí prispôsobit' aj riadiace usporiadanie, ktoré je často redefinované, ako súčast' prípravy na d'alšiu tranžu. Hlavné činnosti v tejto etape sú: Nastavovanie organizácie programu, nastavenie programového úradu, podpora požiadaviek riadenia, nastavenie fyzického prostredia programu, manažment rizika a riešenie nedostatkov, manažment l'udských zdrojov, procurement a manažment zmluvných vzt’ahov, programová komunikácia, reportovanie - monitorovanie - kontrola, manažment informácií, previerky ukončenia tranží a správa bežného podnikania.

4. Delivering the Capability (Dodávanie kapacít) vysvetl'uje, ako bude manažované a kontrolované zoskupenie projektov a d'alších aktivít, ktoré realizujú blueprint. Proces dodania kapacít znamená aktivity pre koordinované a manažované dodanie projektu podl'a programového plánu. Dodanie projektovej sady poskytuje nové výstupy, ktoré sprístupňujú kapacity opísané v blueprinte. Aktivity tohto procesu sú opakované pre každú tranžu programu. Hlavné činnosti $\mathrm{v}$ tejto etape sú: Začatie projektu, prepojenie projektov s realizáciou prínosov, prepojenie projektov s ciel'mi programu, monitorovanie pokroku, manažment rizika a riešenie nezrovnalostí, ukončenie projektu a manažovanie zúčastnených strán

5. Realising the Benefits (Realizovanie prínosov) načrtáva prípravné, realizačné a kontrolné aktivity, potrebné na zrealizovanie výslednej kapacity projektmi, prevod do prevádzky podnikania a jej ustálenie v prevádzke na získanie zamýšl’aných prínosov. Účelom procesu realizovanie je manažovanie prínosov od ich úvodnej identifikácie až po ich úspešnú realizáciu. Aktivity predstavujú monitorovanie pokroku projektov, aby sa zaistilo, že výstupy spĺñajú účel a môžu byt' integrované do operácí́ tak, že prínosy môžu byt' realizované. Tento proces zahŕn̆a plánovanie a manažment zmeny zo starých na nové spôsoby práce a dosahovanie výstupov, zatial'čo sa zaist'uje operačná stabilita a výkonnost' operácií je udržovaná. Aktivity tohto procesu sú opakované pre každú tranžu programu. Dodávanie kapacity a realizácia prínosov sú rozdielne procesy, ale musia úzko spolupracovat', aby sa zosúlad'ovali ciele programu s dodaním projektov a realizácia prínosov cez prechod do prevádzky. Proces manažmentu tranží sa používa pre dohl'ad nad týmito dvomi procesmi, poskytuje vysoko-úrovňové smerovanie, poradenstvo a kontrolu. Hlavné činnosti v tejto etape sú: Stanovenie spôsobu merania prínosov, vyjasnenie profilov prínosov, monitorovanie prínosov, manažovanie prechodu, podpora zmien v personálnom obsadení a kultúre, podpora realizácie prínosov a ich meranie.

6. Closing the Programme (Ukončovanie programu). Tento proces sa vykonáva obyčajne vtedy, ked' bol dodaný blueprint. To znamená, že všetky kapacity vyžadované na dosiahnutie deklarácie vízie sú implementované a boli zrealizované dostatočné prínosy, aby sa dalo objektívne posúdit', či bol program úspešný a byt' presvedčený, že všetky prínosy programu budú dodané v bežnom obchodnom prostredí. Aj po skončení tohto procesu môžu nasledovat' previerky, aby sa dala zhodnotit' a zmerat' pokračujúca realizácia prínosov. Hlavné činnosti v tejto etape sú: Potvrdenie ukončenia programu, zhodnotenie programu, aktualizácia a finalizovanie programových informácií, rozpustenie tímu programového manažmentu, podporných funkcií a informovanie záujmových strán. 


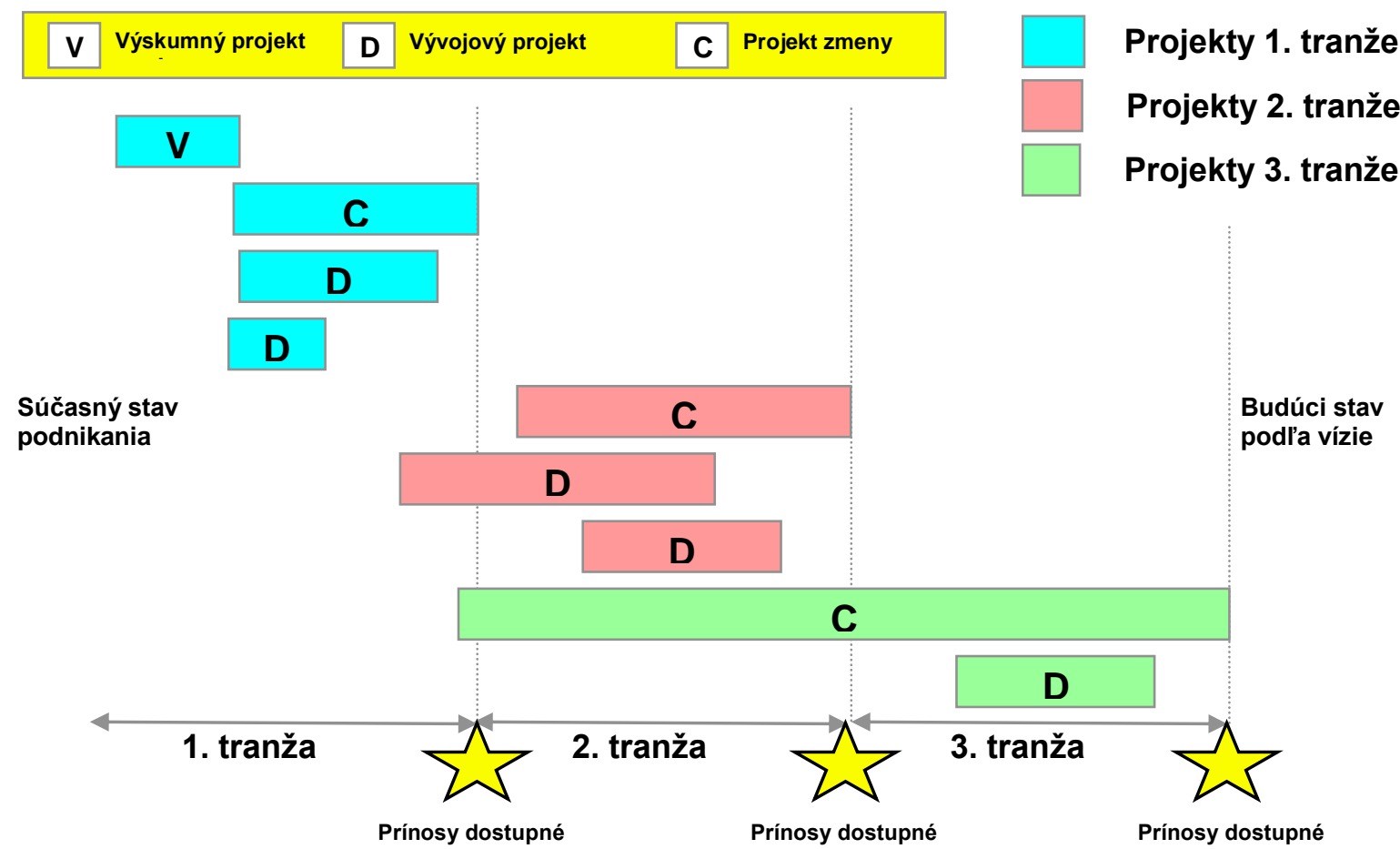

Obr. 2. Projekty zmien vytvárajú prínosy, prebrané a upravené z [9]

\section{Prínosy MSP}

Hlavné prínosy programového manažmentu sú nasledovné [8]:

- Dodáva zmenu efektívnejšie, pretože môžu byt' plánovaná a implementovaná integrovaným spôsobom, zaist'ujúcim, že súčasné obchodné operácie nie sú nepriaznivo ovplyvnené

- Zrovnáva projekty so stratégiou, čo je efektívna odpoved' na strategické iniciatívy premostením medzery medzi firemnými stratégiami a projektmi

- $\quad$ Podnecuje podporu vyššieho manažmentu tým, že pridržiava aktivity sústredené na ciele obchodnej zmeny poskytovaním rámca pre vyšší manažment k smerovaniu a manažovaniu procesu zmeny

- Dosahuje efektívnu koordináciu a riadenie projektov a transformačného toku jasným definovaním úloh a zodpovedností za manažment programu a realizáciu prínosov očakávaných od programu

- Poskytuje plynulý presun od súčasných k budúcim obchodným operáciám prostredníctvom jasného rozpoznania a zodpovednosti za prípravu organizácie na migráciu k novým metódam práce

- Dosahuje skutočné obchodné prínosy prostredníctvom formálneho procesu identifikácie prínosov, manažmentu, realizácie a merania

\section{Záver}

Dnešné organizácie existujú v klíme konštantných a rastúcich zmien. Organizácie, ktoré sa naučili, ako sa transformovat' prostredníctvom efektívneho vedenia a strategickej kontroly, majú väčšiu šancu prežit' a prosperovat'. Programový manažment sa stále viac považuje za kl'úč $\mathrm{k}$ umožneniu organizáciám manažovat' transformáciu.

MSP sa široko využíva britskou vládou a tiež súkromným sektorom, pričom je široko uznávaný a využívaný nielen v Británii, ale aj medzinárodne. Obsahuje zavedenú a overenú 
prax v programovom manažmente. Ponúka spoločný jazyk pre všetkých účastníkov programov a im prislúchajúcich programov a transformačných aktivít.

Ďalšiu z metód pre programový manažment predstavuje Program Management Professional (PgMP) [1], ktorú vytvoril Project Management Institute (PMI). Ďalšou organizáciou s vlastnou metodológiou a certifikáciami je International Association for Project and Program Management (IAPPM) [6].

\section{Literatúra a použité zdroje:}

1. Phillips, Joseph: PgMP Program Management Professional, Mc Graw Hill, 2009, ISBN 0-07-154927-7

2. http://www.ogc.gov.uk/programme_project_management.asp

3. http://www.buzzle.com/articles/understanding-msp-programme-management.html

4. http://www.12manage.com/methods_ogc_msp.html

5. Managing Successful Programmes. The Stationery Office. ISBN: 9780113310401

6. http://www.iappm.org/

7. http://ks.utc.sk/casopis/pdf/I2009/bombala2.pdf

8. http://www.msp-officialsite.com/

9. www.orsoc.org.uk/region/study/infor/PS_SIG_10-04-2003.ppt 